\title{
Milk fatty acid characterization and genetic parameter estimates for milk conjugated linoleic acid in buffaloes
}

\author{
Humberto Tonhati ${ }^{1,4 *}$, André LF Lima ${ }^{2}$, Dante PD Lanna ${ }^{3}$, Gregório MF de Camargo ${ }^{1}$, Fernando Baldi ${ }^{1}$, \\ Lucia G de Albuquerque ${ }^{1,4}$ and Jeanne MCD Montrezor ${ }^{1}$ \\ ${ }^{1}$ Animal Science Department, São Paulo State University (FCAV/Unesp), Jaboticabal, SP, Brazil \\ ${ }^{2}$ Animal Science and Rural Development Department, Santa Catarina Federal University, Florianópolis, SC, Brazil \\ ${ }^{3}$ Animal Science Department, São Paulo University (ESALQ/USP), Piracicaba, SP, Brazil \\ ${ }^{4}$ Conselho Nacional de Desenvolvimento Científico e Tecnologico (CNPq) and Instituto Nacional de Ciência e Tecnologia - Ciência Animal \\ (INCT-CA), Viçosa, MG, Brazil
}

Received 5 November 2010; accepted for publication 31 December 2010; first published online 4 March 2011

\begin{abstract}
The objectives of this study were to analyse buffalo milk fat composition, to verify the activity of Delta (9)-desaturase enzyme in the mammary gland, as well as to estimate additive genetic variances for milk, fat and protein yield, and milk cis-9,trans-11 conjugated linoleic acid percentage (cis-9,trans-11 CLA\%). A total of 3929 lactation milk yields (MY) records from 2130 buffaloes and 1598 lactation fat (FY) and protein (PY) yield records from 914 buffaloes were analysed. For cis-9, trans-11 CLA\% percentage, a total of 661 milk samples from 225 buffaloes, daughters of 8 sires, belonging to 4 herds and calving in 2003 and 2004, were used. The genetic parameters and variance components were estimated by Restricted Maximum Likelihood applying an animal model. The fixed effects considered in the model were: contemporary group (herd, year, calving season) and age at calving (linear and quadratic effects) and lactation length (linear and quadratic effects) as covariables. Additive genetic and permanent environment effects were considered as random. The MY, FY, PY and CLA\% means were $1482 \pm 355 \mathrm{~kg}, 90 \cdot 1 \pm 24 \cdot 6 \mathrm{~kg}, 56 \cdot 9 \pm 15 \cdot 2 \mathrm{~kg}$ and $0 \cdot 69 \pm 0 \cdot 16 \%$, respectively. Heritability estimates for MY, FY, PY and CLA\% were $0.28 \pm 0.05,0.26 \pm 0.11,0.25 \pm 0.11$ and $0.35 \pm 0.14$, respectively. There is enough additive genetic variation for buffalo milk, protein and fat yield to improve these traits through selection. The cis-9,trans-11 CLA\% can be enhanced by selection in buffaloes and will contribute to improving human health. The activity and efficiency of Delta(9)-desaturase in the mammary was measured and confirmed.
\end{abstract}

Keywords: Bubalus bubalis, CLA, heritability, milk fatty acids profile, Delta(9)-desaturase activity.

Conjugated linoleic acid (CLA) is a term used to describe one or more positional and geometric isomers of linoleic acid (cis-9,trans-12 octadecadienoic) with double conjugated bonds. Generally, these bonds are found at 9 and 11 or at 10 and 12 positions, in cis or trans configurations. The isomers with high biological activity are cis-9, trans-11 CLA and trans-10, cis-12 CLA (Pariza et al. 2000). Bovine milk fat is the largest natural source of the cis-9,trans-11 isomer (Nestel et al. 2006).

CLA is an intermediate fatty acid in the biohydrogenation process synthesized by the rumen bacteria, Butyrivibrio fibrisolvens being the best known. Some studies have shown that cis-9,trans-11 CLA may be endogenously synthesized

*For correspondence; tonhati@fcav.unesp.br under the action of Delta(9)-desaturase (Griinari \& Bauman, 1999). This mechanism seems to be responsible for $85 \%$ of the cis-9, trans-11 CLA in milk (Griinari et al. 2000). Delta(9)desaturase mammary activity has been studied using as proxies either the ratios of desaturase products and precursors (e.g. Lock \& Garnsworthy, 2002) or products as a percentage of precursors plus products (e.g. Feng et al. 2007).

The cis-9,trans-11 CLA isomer is recognized for its anticarcinogenic capacity and in many studies this property was confirmed in vivo using both animal models and human tissue cultures (Ha et al. 1987; Ha et al. 1990; Shultz et al. 1992; Ip et al. 1994; Visonneau et al. 1997; Cesano et al. 1998; Ip et al. 1999). Although in several studies the anticancer properties of CLA have been confirmed, only a few have reported anti-atherosclerotic effects. In this sense, Lee et al. (1994) and Gavino et al. (2000) showed that using 
Table 1. Summary of data structure and descriptive statistics for fat yield (FY), protein yield (PY) and milk yield (MY), milk fat (\%F) and protein (\%P) percentage and cis- 9 , trans-11 CLA \%

$\begin{array}{lcccc} & & & & \begin{array}{l}\text { cis-9, } \\ \text { trans-11 }\end{array} \\ \text { Description } & \text { MY }(\mathrm{kg}) & \mathrm{FY}(\mathrm{kg}) & \mathrm{PY}(\mathrm{kg}) & \mathrm{CLA} \% \\ \text { Number of records } & 3929 & 1598 & 1598 & 661 \\ \text { Sire } & 140 & 103 & 103 & 8 \\ \text { Cows } & 1986 & 572 & 572 & 140 \\ \text { Mean } & 1,561 & 90 \cdot 06 & 56 \cdot 96 & 0 \cdot 698 \\ \text { SD } & 354 \cdot 7 & 24 \cdot 59 & 15 \cdot 54 & 0 \cdot 161 \\ \text { Coefficient of } & 23.94 & 27 \cdot 3 & 26 \cdot 75 & 23 \cdot 03 \\ \quad \text { Variation, } \% & & & & \\ \quad \text { No of contemporary } & 156 & 49 & 49 & 32 \\ \quad \text { groups } & & & & \end{array}$

CLA as a dietary supplement reduced aortic atherosclerosis, plasma triglyceride and total cholesterol levels, thus decreasing cardiovascular risk. Another important biological activity of CLA is the modulation of the immune system and the catabolism of skeletal muscle (Pariza et al. 2000).

In western countries, all buffalo milk production is mostly made into mozzarella cheese, an expensive fresh cheese. The artisanal buffalo mozzarella cheese represents a good source of CLA for humans with lower consumption of other lipids (Van Nieuwenhove et al. 2007). Up to now, market attention has increasingly focused on improving the health aspects of fresh milk and dairy derived products. Possibilities to change milk fat composition by selection altering milk $\mathrm{CLA} \%$ is therefore of interest. Improvement through selection of traits associated with milk quality and milk yield for milking buffaloes is dependent on the availability of genetic parameter estimates for these traits.

In dairy cattle, several studies have reported genetic parameter estimates for CLA\% (Stoop et al. 2008; Mele et al. 2009; Garnsworthy et al. 2010). To date, there are no studies reporting CLA\% genetic parameters for milking buffaloes. However, recently, genetic markers have been associated with CLA\% in buffaloes milk. In this sense, Lima et al., (2007) have identified two variants for the promoter region of stearoyl-CoA-desaturase (SCD) in buffaloes. Furthermore, De Camargo et al. (2010) verified that the average substitution effect of these variants was $0.08 \%$ for CLA\% in buffalo milk.

The objectives of this study were to analyse buffalo milk fat composition, to verify the activity of Delta(9)-desaturase enzyme in the mammary gland, as well as to estimate additive genetic variances for milk, fat and protein yield, and milk cis-9, trans-11 CLA\%.

\section{Material and Methods}

Data from the Dairy Bubaline Test Program developed by the Animal Science Department, São Paulo State University, Jaboticabal-SP, Brazil, were used. A total of 3929 lactation milk yield (MY) records from 2130 buffaloes, and 1598 lactation fat (FY) and protein (PY) yields records from 914 buffaloes were analysed. Not all the farms that were used for milk yield analyses had also laboratory analyses available for milk components (fat and protein). Animals were raised on pasture, tropical grasses, with feed supplementation during the dry period from April to September. Milk samples were collected monthly during the lactation and milk components (fat and protein percentage) were determined by the infrared light absorption using Bentley 2000 equipment.

For cis-9,trans-11 CLA\%, a total of 661 milk samples from 225 buffaloes, daughters of 8 sires, belonging to 4 herds and calving in 2003 and 2004, were used. In taking the samples for fatty acid composition analyses, the following criteria were applied: one milk sample was taken at the beginning, at middle and at the end of lactation per cow. All samples were kept in a freezer. Milk samples were thawed and centrifuged at $9000 \mathrm{rpm}$ at $8{ }^{\circ} \mathrm{C}$ for $30 \mathrm{~min}$ to precipitate the fat. An aliquot $(40 \mathrm{mg}$ ) of fat was collected and a solution of hexane-isopropanol was added as described by Hara \& Radin (1978). An adaptation of Chouinard et al. (1999) methodology was used for methylation, using a solution of sodium methoxide. Milk fatty acids were quantified by gas chromatography in a Trace GC 3 equipment/SUPELCO 2-4056 SP ${ }^{\mathrm{TM}}-2560$.

Only lactations from first to fourth order were considered and yields records were truncated at $270 \mathrm{~d}$ of lactation. Milk yield records lower than $500 \mathrm{~kg}$ or higher than $3200 \mathrm{~kg}$, age of cow at calving lower than $700 \mathrm{~d}$, and lactations shorter than $90 \mathrm{~d}$ were excluded from the analyses.

Variance components were estimated using a repeatability animal model, considering fixed effects of contemporary groups (herd, year and calving season) and age of cow at calving and lactation length (linear and quadratic effects) as covariables. Additive genetic and permanent environmental effects were considered as random effects for $M Y, P Y$ and FY. For cis-9,trans-11 CLA\% only additive genetic effect was included as random, since just the first lactation was considered. The model represented in matrix notation, was:

$y=X \beta+Z a+W p+e$

where, $y=a$ vector of observed traits; $X=$ the incidence matrix of fixed effects; $\beta=$ a vector of fixed effects (CG, number of milking and the covariable cow's age at calving as linear and quadratic effects); $Z=$ the incidence matrix of additive genetic random effects; $a=a$ vector of additive genetic random effects; $W=$ the incidence matrix of permanent environmental random effect; $p=$ a vector of permanent environmental random effects; and $e=a$ vector of random error effects.

Genetic parameters were estimated by Restricted Maximum Likelihood method (REML), using MTDFREML software (Boldman et al. 1995). One-trait analyses were performed to estimate the variance components and the genetic parameters. There were 11632 animals in the relationship matrix and all generations back were used. The data structure and descriptive statistics for studied traits are presented in Table 1. 
Table 2. Buffalo milk fatty acids means ( $\%$ fat) and fatty acid ratios

Fatty acids
$4: 0$
$6: 0$
$8: 0$
$10: 0$
$12: 0$
$14: 0$
cis-9,14:1
$15: 0$
$16: 0$
cis-9,16:1
$17: 0$
$18: 0$
trans-11,18:1
cis-9,18:1
cis-9, trans-12,18:2
$18: 3$
cis-9, trans-11CLA $18: 2$
trans-10, cis-12 CLA $18: 2$
$20: 0$
Unsaturated fatty acids $($ UFA)
Saturated fatty acids $(S F A)$
cis-9,14:1/(14:0 + cis-9,14:1)
cis-9,16:1/(16:0 + cis-9,16:1)
cis-9,18:1/(18:0 + cis-9,18:1)
CLA/(linoleic + CLA)
CLA/(vaccenic + CLA)
UFA/SFA

$\%$

$3 \cdot 06$

$1 \cdot 19$

0.53

0.96

$1 \cdot 37$

$7 \cdot 78$

$0 \cdot 4$

0.99

$28 \cdot 67$

$1 \cdot 6$

$0 \cdot 59$

$15 \cdot 67$

$2 \cdot 71$

$22 \cdot 42$

$1 \cdot 28$

$0 \cdot 24$

$0 \cdot 8$

$0 \cdot 12$

$0 \cdot 1$

$33 \cdot 97$

$62 \cdot 89$

$0 \cdot 049$

0.053

$0 \cdot 59$

$0 \cdot 38$

$0 \cdot 23$

$0 \cdot 540$

\section{Results and Discussion}

Milk fatty acid composition and Delta(9)-desaturase enzyme activity

The 16:0, cis-9 18:1, 18:0 and 14:0 fatty acids showed the highest concentrations (Table 2). These results agree with those reported by Palmquist et al. (1993), Jensen (2002) Lock \& Garnsworthy (2003) for milk fat acid composition in dairy cattle. It was observed that $49 \%$ of the fatty acids were long chain acids (>18:0), while medium (14-16) and short $(<14)$ chain fatty acids corresponded to $35 \%$ and $16 \%$ of total, respectively.

Proportions of saturated (SFA) and unsaturated (UFA) fatty acids were $62 \cdot 89 \%$ and $33.97 \%$, respectively (Table 1 ). For buffalo raw milk, Van Nieuwenhove et al. (2007) reported similar SFA and UFA values, $65.9 \%$ and $34.1 \%$, respectively. SFA with the highest percentages were palmitic (16:0), stearic (18:0) and myristic (14:0). Similar results were reported by Van Nieuwenhove et al. (2007) for Argentinean crossbred (Murrah $\times$ Mediterranean breeds) milking buffaloes on ad-libitum intake of natural pasture.

Palmitic and myristic acids decrease the blood low density lipids (LDL) level, so it is important to reduce them in milk fat (Maijala, 2000). UFA with the highest percentages were oleic (cis-9,18:1) and vacenic (trans-11,18:1), 22.42\% and $2 \cdot 71 \%$ of total fat acids, respectively. From the dietary point of view, the ratio of UFA to SFA in buffalo milk (0.54) was above the minimum boundary required (0.50) (Nestel, 1987). Under the action of Delta(9)-desaturase mammary gland enzyme some SFA is converted to UFA, improving milk quality (Lock \& Bauman, 2004).

The mean content of 14:0 obtained in the present study was close to that reported by Fernandes et al. (2007) and Melicio et al. (2005) also working with milking buffaloes, values being 5·96-8·85\%. However, Lock \& Garnsworthy (2003), working with dairy cattle, reported higher values of $9 \cdot 0-11 \cdot 3 \%$ for $14: 0$. For $16: 0$, the mean observed in the present study was similar to those obtained by Fedele et al. (2001) and Fernandes et al. (2007) with buffaloes (25.3-34.4\%). In dairy cattle, Palmquist et al. (1993) and Jensen (2002) reported similar 16:0 mean values, 29.87\% and $30 \cdot 70 \%$ respectively. However, Lock \& Garnsworthy (2003), also in dairy cattle, reported lower 16:0 values $(18 \cdot 70 \%)$ than that found in the present study. The mean $18: 0 \%$ obtained in the present study was similar to those reported by Fedele et al. (2001) and Melicio et al. (2005), working with milking buffaloes (12.6-16.7\%) and by Lock \& Garnsworthy (2003) in dairy cows (14.7\%). Nevertheless, working with milking buffaloes or dairy cattle, lower 18:0\% values $(9 \cdot 0-13 \cdot 4 \%)$ have been reported by Palmquist et al. (1993) Jensen (2002) and Fernandes et al. (2007).

The present results confirm that buffalo milk is an important source of cis-9,trans-11 CLA. Similar conclusions were drawn by Van Nieuwenhove et al. (2007) also for milking buffaloes. In dairy cattle, Stoop et al. (2008), Mele et al. (2009) and Garsnworthy et al. (2010) reported lower CLA\% values compared with that obtained in the present study, being $0.39 \%, 0.35 \%$ and $0.39 \%$, respectively.

In several studies, the mammary Delta(9)-desaturase enzyme activity has been studied by using as proxies either the ratios of desaturase products and precursors or products as a percentage of precursors plus products (Garnsworthy et al. 2010). Delta(9)-desaturase activity in the mammary gland was measured indirectly through the ratio of some fatty acids (product/substrate + product) (Table 2). The cis-9,14:1/ $(14: 0+$ cis-9,14:1) ratio is the index most used to measure the enzyme activity, because the cis-9,14:1 has high levels in milk and low levels in the digest (Lock \& Garnsworthy, 2003; Fievez et al. 2003). The cis-9,14:1/(14:0+cis-9,14:1) ratio obtained in the present study was lower than those reported by Lock \& Garnsworthy (2003) and Fernandes et al. (2007), $0 \cdot 062$ and 0.065 , respectively. However, these authors used the cis-9,14:1/14:0 ratio to evaluate Delta(9)-desaturase enzyme activity. Despite the low cis-9,14:1/(14:0+ cis-9, 14:1) ratio, there is sufficient evidence to confirm that Delta(9)-desaturase enzyme takes part in fatty acid synthesis in the mammary gland in buffaloes.

The factors that affect Delta(9)-desaturase activity are not well explained yet, but probably are influenced by genetic factors, lactation period and nutrition (Lock \& Garnsworthy, 2003). Based on the ratio product/substrate, Fernandes et al. (2007) observed similar cis-9,16:1/16:0 ratio to that obtained in the present study $(0 \cdot 05-0 \cdot 063)$. However, the value obtained in the present study was lower than that reported by 
Table 3. Additive genetic $\left(\sigma_{\mathrm{a}}^{2}\right)$, permanent environment variance $\left(\sigma_{\mathrm{pe}}^{2}\right)$, residual $\left(\sigma_{\mathrm{e}}^{2}\right)$ and phenotypic variance estimates $\left(\sigma_{\mathrm{p}}^{2}\right)$, heritability $\left(\mathrm{h}^{2} \pm \mathrm{SE}\right)$ and repeatability estimates $(\mathrm{t} \pm \mathrm{SE})$ for milk yield $(\mathrm{MY})$, protein $(\mathrm{PY})$ and fat $(\mathrm{FY})$ and cis-9, trans-11 CLA\% (CLA\%)

\begin{tabular}{|c|c|c|c|c|c|c|}
\hline & $\sigma_{a}^{2}$ & $\sigma_{\mathrm{pe}}^{2}$ & $\sigma_{\mathrm{e}}^{2}$ & $\sigma_{p}^{2}$ & $h^{2}$ & $\mathrm{t}$ \\
\hline MY & 34112 & 27571 & 58558 & 120241 & $0 \cdot 28 \pm 0 \cdot 05$ & $0 \cdot 49$ \\
\hline PY & $37 \cdot 2$ & $29 \cdot 0$ & $84 \cdot 2$ & $150 \cdot 5$ & $0 \cdot 25 \pm 0 \cdot 11$ & $0 \cdot 56$ \\
\hline FY & $120 \cdot 5$ & $76 \cdot 0$ & $272 \cdot 4$ & $468 \cdot 9$ & $0 \cdot 26 \pm 0 \cdot 10$ & $0 \cdot 58$ \\
\hline CLA\% & $0 \cdot 014$ & - & 0.025 & 0.039 & $0 \cdot 35 \pm 0 \cdot 14$ & - \\
\hline
\end{tabular}

Lock \& Garnsworthy (2003) (0·079). The ratios of cis-9,18:1/ (18:0 + cis-9,18:1) and cis-9, trans-11 CLA/(vaccenic + cis-9, trans-11 CLA) obtained were similar to those obtained by Lock \& Garnsworthy (2003) (using the product/substrate ratio). Recently, Garnsworthy et al. (2010) evaluated the activity of Delta(9)-desaturase enzyme activity in the mammary gland of Holstein cows and reported higher cis-9,14:1/(14:0 + cis-9,14:1); cis-9,16:1/(16:0 + cis-9,16:1) and cis-9, 18:1/(18:0+cis-9,18:1) ratios, values being $0.081,0.066$ and 0.73 , respectively. However, these authors observed a similar $\mathrm{CLA} /($ vaccenic $+\mathrm{CLA})$ ratio $(0 \cdot 25)$ to that obtained in the present study (Table 2 ). The results obtained in the present study indicated that Delta(9)-desaturase enzyme had an important role in determining the fatty acid composition of milk.

Griinari et al. (2000) also highlighted the importance of Delta(9)-desaturase in the production of cis-9,18:1 and observed that the activity of this enzyme is the major source of cis-9,14:1 and cis-9,16:1 in the milk fat. Considering that approximately $75 \%$ of CLA in milk comes from endogenous synthesis in the mammary gland (Corl et al. 1999) and it was observed that there are differences in the activity of Delta(9)-desaturase (measured by the ratios) suggests that there is variation in the activity of this enzyme. Lock \& Garnsworthy (2003) observed a possible genetic variation among animals for Delta(9)-desaturase activity, because they found a significant difference in the cis-9,14:1/14:0 ratio (a variation from $0 \cdot 039$ to $0 \cdot 121$ ).

\section{Genetic parameter estimates}

Variance components and genetic parameter estimates are presented in Table 3. The MY heritability estimate was moderate and was higher than those obtained by Rosati \& Van Vleck (2002) and Hurtado-Lugo et al. (2006) for milking buffaloes, being $0 \cdot 14$ and $(0 \cdot 01-0 \cdot 20)$, respectively. Tonhati et al. (2000) and Aspilcueta-Borquis et al. (2010 b,c) in Brazilian milking buffaloes and applying REML and Bayesian Inference to estimate the genetic parameters, respectively, obtained similar values $(0 \cdot 24)$ to that reported in the present study.

Heritability estimates for FY and PY were moderate and were in agreement with those obtained by Tonhati et al. (2000) (0.26 and 0.21) and Aspilcueta-Borquis et al. (2010a) (0.23 and 0.22). However, Rosati \& Van Vleck (2002) in Italy, obtained lower and higher heritability estimates for PY and FY, respectively, than those obtained in the present study, values being $0 \cdot 14$ and $0 \cdot 38$.
Heritability estimates obtained for MY, PY and FY indicate that these traits should respond to selection. Differences in the variance component methods and also in population studied, probably explain the divergence between the results obtained in the present study and previous studies.

The CLA\% heritability estimate was moderate (Table 3), indicating that this trait is influenced by additive genetic effects. Thus, it is possible to obtain genetic gain and increase the population mean for this trait, improving the nutritional properties of milk fat through selection. As reported by Kelly et al. (1998), Lawless et al. (1998) and Fernandes et al. (2007), there is great variation in \%CLA among animals raised in the same herd and under the same management and feeding conditions.

In dairy cattle, Stoop et al. (2008), Mele et al. (2009) and Garnsworthy et al. (2010) reported lower CLA\% heritability estimates than that obtained in the present study, values being $0 \cdot 21,0 \cdot 12$ and $0 \cdot 02$, respectively. Carta et al. (2003) observed marked variability in CLA content between families in milking sheep. Indeed, the sire variance estimated by the authors was $7 \cdot 7 \%$ of the total phenotypic variance. Despite being based on a limited number of cows, daughters from eight sires and belonging to four herds (which led to larger standard errors of genetic estimates), the present study is the first one describing buffalo genetic parameters for CLA\%.

It was not possible to carry out multiple-trait analyses in order to obtain an accurate estimation of genetic correlations, since there are a small number of buffaloes with CLA\% records. So, future studies should contemplate these parameters with the aim of clarifying the genetic associations among milk, fat and protein production with CLA\% before establishing selection criteria to increase milk quality. The phenotypic correlation estimates between CLA\% and MY, PY and FY were $0 \cdot 18,0 \cdot 32$ and $0 \cdot 21$, respectively. These results suggest that the phenotypic association between CLA \% and milk yield and milk components (fat and protein) were low.

MY, PY and FY repeatability estimates were moderate to high (Table 3). Tonhati et al. (2000) reported lower estimates of repeatability $(0 \cdot 38)$ for $M Y$ than that obtained in the present study. PY and FY repeatability estimates were higher than those obtained by Tonhati et al. (2000), being 0.30 (PY) and 0.28 (FY). The results obtained in the present study indicate that MY, PY and FY records could be applied to predict future records based on observed records.

In conclusion, there is enough additive genetic variation for buffalo milk, protein and fat yield to improve these traits 
through selection. The cis-9,trans-11 CLA percentage can be enhanced by selection in buffaloes and will contribute to improving human health. The activity and efficiency of Delta(9)-desaturase in the mammary was measured and confirmed, indicating that it could be used in order to improve the fatty acid profile of buffalo milk.

The authors thank the buffalo breeders that participated of the milk-test program and provided the data for this study, as well as the Conselho Nacional de Desenvolvimento Científico e Tecnológico $(\mathrm{CNPq})$ and to the Fundação de Apoio à Pesquisa do Estado de São Paulo (FAPESP) for financial support.

\section{References}

Aspilcueta-Borquis RR, Sesana RC, Muñoz-Berrocal MH, Seno LO, Bignardi AB, El Faro L, Albuquerque LG, de Camargo GMF \& Tonhati H 2010a Genetic parameters for milk, fat and protein yields in Murrah buffaloes (Bubalus bubalis Artiodactyla, Bovidae). Genetics and Molecular Biology 33 71-77

Aspilcueta-Borquis RR, Di Palo R, Araújo Neto FR, Baldi F, de Camargo GMF, Albuquerque LG, Zicarelli L \& Tonhati H 2010b Genetic parameter estimates for buffalo milk yield, milk quality and mozzarella production and Bayesian inference analysis of their relationships. Genetics and Molecular Research 9 1636-1644

Aspilcueta-Borquis RR, Araújo Neto FR, Baldi F, Bignardi AB, Albuquerque LG \& Tonhati H 2010c Genetic parameters for buffalo milk yield and milk quality traits using Bayesian inference. Journal of Dairy Science $\mathbf{9 3}$ 2195-2201

Boldman KG, Kriese LA, Van Vleck LD \& Kachman SD 1995 A Manual for use MTDFREML. Department of Agriculture/Agricultural Research Service, Lincoln NE, USA 120 pp.

Carta A, Piredda G, Addis M, Cabiddu A, Fiori M, Leroux C \& Barillet F 2003 Fatty acid composition of sheep milk from a backcross Sarda $\times$ Lacaune resource population: Preliminary QTL detection for CLA content. In: Breeding Programmes for Improving the Quality and Safety of Products. New Traits, Tools, Rules and Organization? (Eds D Gabiña \& S Sanna) pp. 107-113. Zaragoza, Spain: CIHEAM-IAMZ

Cesano A, Visonneau S, Scimeca JA, Kritchevsky D \& Santoli D 1998 Opposite effects of linoleic acid and conjugated linoleic acid on human prostatic cancer in SCID mice. Anticancer Research 18 1429-1434

Chouinard PY, Corneau L, Barbano DM, Metzger LE \& Bauman DE 1999 Conjugated linoleic acids alter milk fatty acid composition and inhibit milk fat secretion in dairy cows. Journal of Nutrition 129 1579-1584

Corl BA, Lacy SH, Baumgard LH, Dwyer DA, Griinari JM, Phillips S \& Bauman DE 1999 Examination of the importance of $\Delta^{9}$-dessaturase and endogenous synthesis of conjugated linoleic acid in lactating dairy cows. Animal Science 77118

De Camargo GMF, Lima ALF, Thomazine RB, Baldi F, Albuquerque LG \& Tonhati H 2010 Stearoyl-CoA-Desaturase's promoter region of buffaloes and its correlation with conjugated linoleic acid in milk. $26^{\text {th }}$ World Buiatrics Congress, Santiago, Chile

Fedele E, lannibeci L, Marzillo G, Ferrara L \& Bergamo P 2001 Conjugated linoleic acid content in milk and mozzarela cheese from buffalo fed with organic and traditional diet. In: World Buffalo Congress, 6. Maracaibo, Proceedings. Maracaibo: Zulia University. Technology Park, 404-409

Feng S, Salter AM, Parr T \& Garnsworthy PC 2007 Extraction and quantitative analysis of stearoyl-coenzyme A desaturase mRNA from dairy cow milk somatic cells. Journal of Dairy Science $\mathbf{9 0} 4128-4136$

Fernandes SAA, Mattos WRS, Matarazzo SV, Tonhati H, Sundfeld Gama MA \& Lanna DPD 2007 Activity of $\Delta$ 9-desaturase enzyme in mammary gland of lactating buffaloes. Italian Journal of Animal Science 6 1060-1062

Fievez V, Vlaeminck B, Dhanoa MS \& Dewhurst RJ 2003 Use of principal components analysis to investigate the origin of heptadecenoic acid and conjugated linoleic acids in milk. Journal of Dairy Science 86 1017-1053
Gavino VC, Gavino G, Leblanc MJ \& Tuchweber B 2000 An isomeric mixture of conjugated linoleic acids but not pure cis-9,trans-11octadecadienoic acid affects body weight and plasma lipids in hamsters. Journal Nutrition 130 27-29

Garnsworthy PC, Feng S, Lock AL \& Royal MD 2010 Heritability of milk fatty acid composition and stearoyl-CoA desaturase indices in dairy cows. Journal of Dairy Science 93 1743-1748

Griinari JM \& Bauman DE 1999 Biosynthesis of conjugated linoleic acid and its incorporation into meat and milk in ruminants. In: Advances in Conjugated Linoleic acid Research Vol 1 (Eds MP Yurawecz, MM Mossoba, JKG Kramer et al.) pp. 180-200. Champaign IL, USA: American Oil Chemists Society Press

Griinari JM, Corl BA, Lacy SH, Chouinard PY, Nurmela KVV \& Bauman DE 2000 Conjugated linoleic acid is synthesized endogenously in lactating dairy cows by Delta(9)-desaturase. Journal of Nutrition 130 2285-2291

Ha YL, Grimm NK \& Pariza MW 1987 Anticarcinogens from fried ground beef: heat-altered derivatives of linoleic acid. Carcinogenesis $\mathbf{8}$ 1881-1887

Ha YL, Storkson J \& Pariza MW 1990 Inhibition of benzo(a)pyrene-induced mouse forestomach neoplasia by conjugated dienoic derivatives of linoleic acid. Cancer Research 50 1097-1101

Hara A \& Radim NS 1978 Lipid extraction of tissues with low toxicity solvent. Analytical Biochemistry 90 420-426

Hurtado-Lugo N, Cerón-Muñoz M \& Gutiérrez-Valencia A 2006 [Estimation of genetic parameters for milk production on control days in buffaloes in Costa Atlántica Colombia]. Livestock Research for Rural Development 183 www.cipav.org.co/lrrd//rrd18/3/hurt18039.htm

Ip C, Singh M, Thompson HJ \& Scimeca JA 1994 Conjugated linoleic acid suppresses mammary carcinogenesis and proliferative activity of the mammary gland in the rat. Cancer Research 54 1212-1215

Ip C, Banni S, Angioni E, Carta G, McGinley J, Thompson HJ, Barbano D \& Bauman DE 1999 Conjugated linoleic acid-enriched butter fat alters mammary gland morphogenesis and reduces cancer risk in rats. Journal of Nutrition 129 2135-2142

Jensen RG 2002 The composition of bovine milk lipids: January 1995 to December 2000. Journal of Dairy Science 85 295-350

Kelly ML, Berry JR, Dwyer DA, Griinari JM, Chouinard PY, Van Amburgh ME \& Bauman DE 1998 Dietary fatty acid sources affect conjugated linoleic acid concentrations in milk from lactating dairy cows. Journal of Nutrition 128 881-885

Lawless F, Murphy JJ, Harrington D, Devery R \& Stanton C 1998 Elevation of conjugated cis-9, trans-11-octadecadiencoic acid in bovine milk because of dietary supplementation. Journal Animal Science $\mathbf{8 1}$ 3259-3267

Lima ALF, Otaviano AR, Laureano MMM, Galeazzi PM, de Camargo GMF, Thomazine RB \& Tonhati H 2007 Partial genetic characterization of Stearoyl CoA-Desaturase's structural region in Bubalus bubalis. Italian Journal of Animal Science 6 287-290

Lee KN, Kritchevsky D \& Pariza MW 1994 Conjugated linoleic acid an atherosclerosis in rabbits. Atherosclerosis 108 19-25

Lock AL \& Garnsworthy PC 2003 Seasonal variation in milk conjugated linoleic acid and Delta(9)-desaturase activity in dairy cows. Livestock Production Science 79 47-59

Lock AL \& Bauman DE 2004 Modifying milk fat composition of dairy cows to enhance fatty acids beneficial to human health. Lipids $\mathbf{3 9}$ 1197-1206

Maijala K 2000 Cow milk and human development and well-being. Livestock Production Science 65 1-18

Mele M, Dal Zotto R, Cassandro M, Conte G, Serra A, Buccioni A, Bittante G \& Secchiari P 2009 Genetic parameters for conjugated linoleic acid selected milk fatty acids, and milk fatty acid unsaturation of Italian Holstein-Friesian cows. Journal of Dairy Science 92 392-400

Melício SPL, Carvalho MRBC, Tonhati H, Munari DP, Holgado APR, Larosa G \& Aiura FS 2005 [Chemical composition of milk of Murrah buffaloes in the São Carlos region]. Revista do Instituto de Laticínios Cândido Tostes 60 346-347

Nestel PJ 1987 Polyunsaturated fatty acids (n-3, n-6). American Journal of Clinical Nutrition 45 1161-1167 
Nestel P, Fujii A \& Allen T 2006 The cis-9,trans-11 isomer of conjugated linoleic acid (CLA) lowers plasma triglyceride and raises HDL cholesterol concentrations but does not suppress aortic atherosclerosis in diabetic apoE-deficient mice. Atherosclerosis 189 282-287

Palmquist DL, Beaulieu AD \& Barbano DM 1993 Feed and animal factors influencing milk fat composition. Journal of Dairy Science 76 1753-1771

Pariza MW, Park Y \& Cook ME 2000 Mechanisms of action of conjugated linoleic acid: evidence and speculation. Proceedings of the Society for Experimental Biology and Medicine 223 8-13

Rosati A \& Van Vleck LD 2002 Estimation of genetic parameters for milk, fat, protein and mozzarella cheese production in Italian river buffalo population. Livestock Production Science 74 185-190

Shultz TD, Chew BP, Seaman WR \& Luedecke LO 1992 Inhibitory effect of conjugated dienoic derivatives of linoleic acid and $\beta$-carotene on the in vitro growth of human cancer cells. Cancer Letters 63 125-133

Stoop WM, van Arendonk JAM, Heck JML, van Valenberg HJF \& Bovenhuis H 2008 Genetic parameters for major milk fatty acids and milk production traits of Dutch Holstein-Friesians. Journal of Dairy Science 91 385-394

Tonhati H, Cerón-Muñoz M, Oliveira JA, Duarte JMC, Furtado TP \& Tseimazides SP 2000 [Genetic parameters for the production of milk, fat and protein in buffaloes]. Brazilian Journal of Animal Science $\mathbf{2 9}$ 2051-2056

Van Nieuwenhove C, Gauffin P, Pérez AC \& Silvia G 2007 Chemical composition and fatty acid content of Buffalo cheese from northwest Argentina: effect on lipid composition of mice tissues. Journal of Food Lipids 14 232-243

Visonneau S, Cesano A, Tepper SA, Scimeca JA, Santoli D \& Kritchevsky D 1997 Conjugated linoleic acid suppresses the growth of human breast adenocarcinoma cells in SCID mice. Anticancer Research 17 969-974

White SL, Bertrand JA, Wade MR, Washburn SP, Green JT \& Jenkins TC 2001 Comparison of fatty acid content of milk from Jersey and Holstein cows consuming pasture or a total mixed ration. Journal of Dairy Science 84 2295-2301 